\title{
The Acute Phase Protein Complement 1 Inhibitor is an Indicator of Arterial Stiffness
}

\author{
Jong Kwon Park \\ Inje University College of Medicine, Haeundae \\ Paik Hospital, Department of Surgery Busan \\ Republic of Korea
}

\section{Introduction}

An acute phase protein has been defined as a protein whose plasma concentration increases (positive acute phase protein) or decreases (negative acute phase protein) by at least 25 percent during an inflammatory condition (Gabay \& Kushner, 1999). The complement system is a biochemical cascade and major effecter mechanism of humoral or innate immunity. However, the complement system also has the potential to damage host tissues; thus, its activation must be tightly regulated (Zanker, 2008). Spontaneous complement activation continuously occurs at a low level, and if such activation is not appropriately controlled, damage to normal cells and tissues can occur.

Complement 1 (C1) inhibitor is a naturally occurring serine proteinase inhibitor that inhibits activated $\mathrm{C} 1 \mathrm{~s}$ and $\mathrm{C} 1 \mathrm{r}$, components of the classical complement pathway. It also inhibits other plasma serine proteinases, such as factors XIa and XIIa, plasmin, and kallikrein (Caliezi et al., 2000). C1 inhibitor is essentially an acute phase protein whose plasma level may increase 2- to 2.5-fold during an inflammatory episode (Kalter et al., 1985; Woo et al., 1985). Arteriosclerosis or arterial stiffness is hardening of the artery due to the loss of elasticity through any cause. On the other hand, atherosclerosis is a chronic inflammatory disease of the artery characterized by hardening of the artery specifically due to an atheromatous plaque or inflammation in the arterial wall (Kostner et al., 2006; Jani \& Rajkumar, 2006; Ridker \& Silvertown, 2008; Wykretowicz et al., 2009). Atherosclerosis is the most common form of arteriosclerosis, and is known to be positively correlated with brachial-ankle pulse wave velocity (baPWV), a parameter of arterial stiffness (Imanishi et al., 2004; Jani \& Rajkumar, 2006; Nicoletti et al., 2000; van Popele et al., 2001; Wykretowicz et al., 2009; Yamashina et al., 2003). baPWV is a non-invasive test for arterial stiffness that has been used in large-scale population studies, and has become available in the clinical setting (Yamashina et al., 2002). Previous studies have shown that activation of the complement system is involved in the pathogenesis of atherosclerosis (Bhatia et al., 2007; Fosbrink et al., 2006; Niculescu \& Rus, 2004; Oksjoki et al., 2003, 2007; Thorbjornsdottir et al., 2005; Yasojima et al., 2001). If atherosclerosis develops, inflammation of the arterial wall, increased arterial stiffness, and accompanying activation of the complement system simultaneously occur and progress. Production of the acute phase protein $\mathrm{C} 1$ inhibitor may also increase to regulate over-activation of the complement system. This chapter describes the role of the 
complement system in the development of atherosclerosis and the relationship between the acute phase protein $\mathrm{C} 1$ inhibitor and arterial stiffness.

\section{Complement activation is involved in the development of atherosclerosis}

The complement system was first identified by Bordet, who discovered serum factors that were inactivated by heat and assisted or complemented the lytic function of antibodies. The complement system is composed of plasma proteins that are normally inactive. However, under certain conditions, such as infection, trauma, surgery, burns, tissue infarction, various immunologically mediated and crystal-induced inflammatory conditions, and advanced cancer, they become activated and generate substances that mediate various effecter functions of the complement system. C3, C4, C9, Factor B, C1 inhibitor, C4b-binding protein (C4BP), and mannose-binding lectin are typical complements that are positive acute phase proteins (Gabay \& Kushner, 1999). At the time of complement activation, regulators of complement activation are generated to limit over-activation of the complement system. C1 inhibitor, Factor I, Factor H, C4BP, membrane cofactor for protein (MCP CD46), decayaccelerating factor (DAF), and CD59 are well known regulators of complement activation (Abbas et al., 2010). Activation of the complement system has been suggested to be involved in the development of atherosclerosis, and there is extensive circumstantial evidence to support this hypothesis.

Vaccinia virus complement control protein (VCP) is a complement activation inhibitor. In an animal study of mice with diet-induced atherosclerosis, VCP was injected into the mice regularly once per week after 8 weeks of a high-fat diet. On microscopic examination, the atherosclerotic lesion at the aortic root exhibited a significant $(50 \%)$ reduction in lesion size at 15 weeks (Thorbjornsdottir et al., 2005). This finding demonstrates that inhibition of complement activation slows the progression of atherosclerosis, and indicates the central role of the complement system in the pathogenesis of atherosclerotic disease. Atherosclerosis is essentially a chronic inflammatory disease of the arteries.

Inflammation and immunity, including the complement system, play important roles in the development of atherosclerosis. Activation of the complement system occurs in human atherosclerotic lesions and is regulated by local synthesis of complement components and accompanying complement regulatory proteins. It has been documented that potential triggers of complement activation in the arterial intima include immunocomplexes, Creactive protein (CRP), modified lipoproteins, apoptotic cells, and cholesterol crystals (Oksjoki et al., 2003). Recently, it has been shown that enzymatically modified low-density lipoprotein (LDL) efficiently triggers $\mathrm{C} 1$ activation in the presence of excess $\mathrm{C} 1$ inhibitor (Biro et al., 2007). This result suggests that activation of the classical complement pathway by modified LDL may be important in the development of atherosclerosis. Clearance of apoptotic cells by phagocytes is important in the pathogenesis of atherosclerotic disease, and also plays a role in progression of atherosclerotic plaque (Seimon \& Tabas, 2009).

In the early lesion, when apoptotic cells are present in atherosclerotic plaque, activation of $\mathrm{C} 1$ is important to prevent atherosclerotic plaque from progressing, likely through enhanced phagocytosis and subsequent removal of apoptotic cells. C1q has been found to be expressed on dendritic cells residing in the arterial wall (Cao et al., 2003). Professional phagocytes such as macrophages or dendritic cells expressing $\mathrm{Clq}$ are assumed to clear apoptotic cells from atherosclerotic lesions. In a recent study of C1q-deficient mice and normal C1q mice, the aortic roots were examined after feeding the mice a normal rodent diet 
for 22 weeks. In the aortic roots, apoptotic cells were detected in the C1q-deficient mice, but not in the normal-C1q mice; the C1q-deficient mice had 3-fold larger atherosclerotic lesions than the normal-C1q mice (Bhatia et al., 2007). This experiment suggests that activation of complement $\mathrm{C} 1$ in the early lesion reduces atherosclerotic plaque by enhancing the removal of apoptotic cells from the arterial wall, and that clearing apoptotic cells may be an important mechanism in preventing progression of the atherosclerotic lesion in the early stage of atherosclerosis. However, in the late stage of atherosclerosis, because phagocytosis of apoptotic cells by macrophages is significantly impaired, the detrimental effects of phagocytosis of lipoproteins, platelets, and erythrocytes outweigh the benefits of apoptotic cell uptake. Hence, atherosclerosis progresses despite phagocytosis of substances in the atherosclerotic lesion by macrophages (Schrijvers et al., 2007).

Recent studies have provided additional direct evidence that complement activation is crucial in the development of atherosclerosis. mRNA of $\mathrm{C} 1 \mathrm{r}$ and $\mathrm{C} 1 \mathrm{~s}$ in atherosclerotic plaque has been shown to increase by 2.35 - and 4.96-fold, respectively, compared to in normal arteries (Yasojima et al., 2001). These results indicate that $C 1$ is locally synthesized in atherosclerotic lesions. C4BP is a major inhibitor of the classical complement pathway by interfering with the binding of $\mathrm{C} 4 \mathrm{~b}$ with $\mathrm{C} 2 \mathrm{~b}$ to form $\mathrm{C} 4 \mathrm{~b} 2 \mathrm{~b}$, the $\mathrm{C} 3$ convertase of the classical complement pathway. Immunohistochemistry of human coronary arteries has shown C4BP to be virtually absent in normal arteries, but present in early and advanced atherosclerotic lesions (Oksjoki et al., 2007). This finding suggests that complement activation occurs in atherosclerotic lesions, and the accompanying regulator of complement activation C4BP actively participates in controlling complement activation.

The final step of complement activation is the formation of C5b-9, the membrane attack complex (MAC). In human and experimental atherosclerosis, C5b-9 deposition has been found in atherosclerotic lesions (Niculescu \& Rus, 2004; Niculescu et al., 2004). Moreover, C5b-9 has been demonstrated to induce endothelial cell proliferation and migration in the aorta (Fosbrink et al., 2006). CD59 blocks C9 binding and inhibits formation of the MAC. Experiments with CD59 knockout mice showed that a CD59 deficiency accelerates development of atherosclerotic lesions and increases the plaque vascular smooth muscle cell composition (Wu et al., 2009; Yun et al., 2008). These results indicate that formation of the MAC is an important mechanism of atherogenesis. Activation of the complement 3 component is a key process in formation of the MAC. Complement 3 is the most abundant complement protein and plays a central role in the cascade of complement activation, classical, alternative, and lectin pathways.

Hepatocytes are the main source of C3; however, peripheral white blood cells (PWBCs) such as monocytes, macrophages, lymphocytes, and neutrophils also produce C 3 in the blood stream (Einstein et al., 1977; Morgan \& Gasque, 1997; Moshage, 1997). Previous studies have provided direct evidence that C3 is involved in the development of atherosclerotic lesions. In an animal study with mice, following intravenous injection of $20 \%$ Intralipid, C3 was observed to bind to albumin-encapsulated microbubbles and mediate microbubble adherence to the vascular endothelium during the atherosclerotic process (Anderson et al., 2007). In another mouse model animal study, in which a venous interposition was placed in the common carotid artery, interference with C3 activation resulted in a decrease in vein graft thickening (Schepers et al., 2006). DAF (CD 55) is a membrane protein that regulates complement pathway activity at the level of C3. An animal experiment with DAF knockout mice revealed that DAF deficiency increased deposition of C3d and C5b-9, and accelerated atherosclerotic lesion development (Leung et al., 2009). The results of these studies strongly 
suggest that activation of the complement system and induction of complement regulatory molecules are actively involved in the pathogenesis of atherosclerosis. High C3 is characteristic of progression of atherosclerosis. C3 has significant independent correlations with atherosclerotic risk factors, such as triglyceride, LDL, cholesterol, and cigarette smoking (Ajjan et al., 2005; Capuano et al., 2006). In women, C3 $\geq 1.8 \mathrm{~g} / \mathrm{L}$ has been suggested as a value predictive of major complications of atherosclerosis (Szeplaki et al., 2004). The author has also shown that $C 3$ has a strong positive correlation with baWPV, a measure of arterial stiffness (Table 1) (Chae \& Park, 2009). In this study, C3 increased with baPWV, indicating that $\mathrm{C} 3$ has the potential to predict the extent and severity of atherosclerotic lesions.

\begin{tabular}{lcc}
\hline Variables & Coefficient & $P$ \\
\hline Age & 0.713 & $<0.001^{*}$ \\
BMI & 0.362 & $<0.001^{*}$ \\
Total cholesterol & 0.070 & $0.484^{*}$ \\
LDL & 0.037 & $0.710^{*}$ \\
HDL & -0.243 & $0.014^{\dagger}$ \\
TG & 0.349 & $<0.001^{\dagger}$ \\
HbA1C & 0.414 & $<0.001^{\dagger}$ \\
C1 inhibitor & 0.329 & $<0.001^{*}$ \\
C3 & 0.329 & $<0.001^{*}$ \\
ESR & 0.129 & $0.199{ }^{\dagger}$ \\
CRP & 0.324 & $<0.001^{\dagger}$ \\
\hline
\end{tabular}

*Pearson correlation (variables with a normal distribution); †Spearman correlation (variables without a normal distribution); $\mathrm{P}<0.05$ was considered significant.

Table 1. Univariate correlations between brachial-ankle pulse wave velocity and patient characteristics

\subsection{Complement 1 inhibitor}

$\mathrm{C} 1$ inhibitor, a serine protease inhibitor, is one regulator of the complement system (Abbas et al., 2010). C1 inhibitor is a positive acute phase protein, and its blood level escalates under inflammatory conditions. Sixteen hours after acute myocardial infarction, plasma C1rC1s-C1 inhibitor complex increases 8-fold (Gabay \& Kushner, 1999; Langlois \& Gawryl, 1988). Increased production of $\mathrm{C} 1$ inhibitor in atherosclerosis is a systemic response to a local inflammatory condition in the atherosclerotic lesion. Although mRNA for C1r and C1s in atherosclerotic plaque increased by 2.35- and 4.96-fold compared to a normal artery, mRNA for $\mathrm{C} 1$ inhibitor did not show any significant difference between atherosclerotic plaque and a normal artery (Yasojima et al., 2001). These results suggest that the acute phase protein C1 inhibitor is not produced locally at the atherosclerotic lesion in the artery, but is synthesized in other cells or tissues as a systemic response. Although hepatocytes are the main source of C1 inhibitor, many other cells, including mononuclear phagocytes, microglial cells, fibroblasts, umbilical vein endothelial cells, the placenta, and megakaryocytes also synthesize and secrete C1 inhibitor into the blood stream (Carter et al., 1988; Lappin \& Whaley, 1989; Prada et al., 1998; Zuraw \& Lotz, 1990). The primary roles of C1 inhibitor are regulation of the activation of the classical complement pathway and of the contact system of kinin formation (Prada et al., 1998). The observed strong positive correlation between C1 
inhibitor and C3 indicates that C1 inhibitor actively regulates the cascade of complement activation and coincides with the primary role of C1 inhibitor (Table 2) (Chae \& Park, 2009). Moreover, the fact that $\mathrm{C} 1$ inhibitor also has significant correlation with the inflammatory marker CRP suggests that $\mathrm{C} 1$ inhibitor is another inflammatory marker which can reflect the inflammatory condition in atherosclerotic lesion (Table 2) (Chae \& Park, 2009).

\begin{tabular}{lll}
\hline Inflammatory marker & Coefficient & $P$ \\
\hline C3 & 0.359 & $<0.001$ \\
ESR & 0.111 & 0.269 \\
CRP & 0.242 & 0.015 \\
\hline
\end{tabular}

Spearman correlation; $\mathrm{P}<0.05$ was considered significant.

Table 2. Relationships between $\mathrm{C} 1$ inhibitor and inflammatory markers

The molecular weight of C1 inhibitor is $104 \mathrm{kD}$. C1 inhibitor interacts with C1r and C1s, subsequently dissociating them from C1q. The normal human serum concentration of $\mathrm{C} 1$ inhibitor is $200-230 \mu \mathrm{g} / \mathrm{ml}$. In an experiment with $\mathrm{C} 1$ inhibitor-depleted serum, the minimum concentration of $\mathrm{C} 1$ inhibitor that limits spontaneous $\mathrm{C} 1$ activation was shown to be $55 \mu \mathrm{g} / \mathrm{ml}$ (22\% of the normal concentration) (Windfuhr et al., 2005). C1 inhibitor exerts an anti-inflammatory and anti-apoptotic action on ischemic reperfusion injury, and it has been determined that the mechanism of the action is decreased mRNA expression of the adhesion molecules P-selectin and ICAM-1, induced by ischemic insult. C1 inhibitor also significantly downregulates the pro-inflammatory cytokines TNF-a and IL-18, although it increases protective cytokine IL-6 and IL-10 gene expression (Storini et al., 2005).

\subsection{Brachial-ankle pulse wave velocity}

baPWV is a noninvasive test for measuring arterial stiffness. In recent years, baPWV has become more widely available and used in clinical settings as a simple test for predicting the prognosis of patients (Farrar et al., 1978; Hung et al., 2009; Kim et al., 2008; Tomiyama et al., 2005; van Popele et al., 2001; Xu et al., 2008). Carotid femoral pulse wave velocity (cfPWV) and baPWV are frequently used clinical tests for measuring arterial stiffness, and both have clinical significance. In a multicenter study involving 2287 patients, there was a significant positive correlation between baPWV and cfPWV (Tanaka et al., 2009). baPWV is easy to conduct, and its clinical significance has been demonstrated in many studies. baPWV is measured in a stable environment (Chae \& Park, 2009). The examination is performed in the morning after 10 minutes of rest in a temperature-controlled warm room $\left(24 \pm 1{ }^{\circ} \mathrm{C}\right)$. Measurements are performed in the supine position. Waveforms are obtained from volume plethysmographic sensors in cuffs on the right brachium and both ankles. The time interval $\left(\Delta \mathrm{T}_{\mathrm{ba}}\right)$ between the wave at the right brachium and at the ankles is recorded automatically by the machine. The distance between the sampling points is calculated using the following equations (Yamashina et al., 2002): $\mathrm{L}_{\mathrm{b}}$ is the length from the suprasternal notch to the right brachium, and $\mathrm{L}_{\mathrm{a}}$ is the length from the suprasternal notch to the ankle.

$$
\begin{aligned}
\mathrm{L}_{\mathrm{b}}= & 0.2195 \times \text { height }(\mathrm{cm})-2.0734 \\
\mathrm{~L}_{\mathrm{a}}= & 0.8129 \times \text { height }(\mathrm{cm})+12.328 \\
& \mathrm{baPWV}=\left(\mathrm{L}_{\mathrm{a}}-\mathrm{L}_{\mathrm{b}}\right) / \Delta \mathrm{T}_{\mathrm{ba}}
\end{aligned}
$$


The average values of the right and left baPWVs are used in the statistical analysis. The validity and reproducibility of baPWV measurements are high, and this method appears to be an acceptable indicator of vascular damage (Yamashina et al., 2002). In the author's study, using a volume plethysmographic apparatus (Vasoguard, model P84; Nicolet Vascular, Golden, CO, USA), inter-observer (reproducibility) and intra-observer reliability (repeatability), calculated using the intraclass correlation coefficient (ICC), were 0.8783 and 0.8927, respectively, indicating excellent reproducibility and repeatability (Fig. 1) (Chae \& Park, 2009).

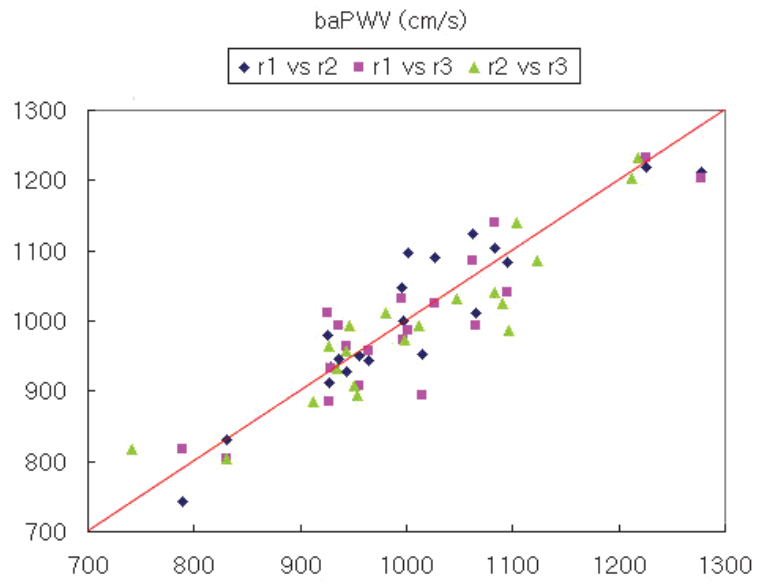

a)

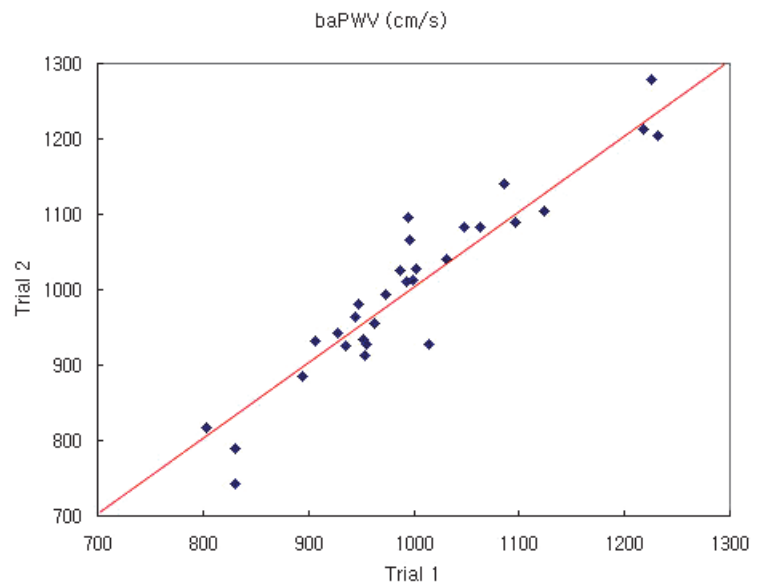

b)

Fig. 1. Inter-observer and intra-observer reliability of measurements of the brachial-ankle pulse wave velocity $(\mathrm{cm} / \mathrm{s})$. A) Inter-observer reliability (reproducibility) shows relationships for three independent measurements by three observers, r1 (observer 1), r2 (observer 2), and $\mathrm{r} 3$ (observer 3 ). The ICC value is 0.8783 . B) Intra-observer reliability (repeatability) shows the relationship between two different measurement trials by one observer. The ICC value is 0.8927 . 
Vascular aging leads to loss of arterial elasticity and reduced arterial compliance. The single most important factor related to increased baPWV is age (Jani \& Rajkumar, 2006; Tomiyama et al., 2003; Wykretowicz et al., 2009). Based on a study of 7881 healthy subjects (4488 males and 3393 females, 25-87 years old) without any atherogenic risk factors, it was determined that aging influences baPWV and its effect is more prominent in females (Tomiyama et al., 2003). The author has also demonstrated that baPWV increases in proportion to advancing age in both males and females, and that females had a stronger correlation between age and baPWV than males (Fig. 2) (Chae \& Park, 2009).

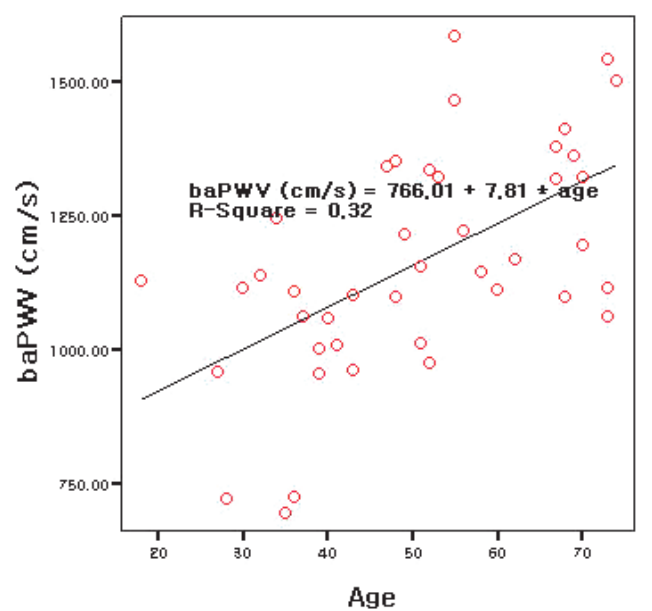

b)

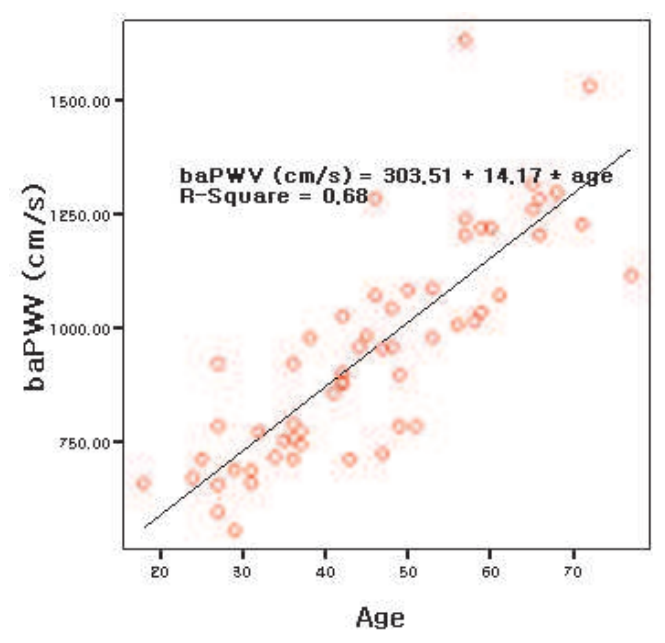

b)

Fig. 2. Linear regression graphs between baPWV and age in both males and females. A) male, B) female, baPWVs increase in proportion to the age in both males and females. 
The mechanism of the more prominent relationship between age and baPWV in females compared to males is not clear; however, menopause appears to be a critical process that augments the increase in arterial stiffness with age in females, according to the author's and other reports (Tomiyama et al., 2003). Clinically, baPWV serves as an indicator of either atherosclerotic cardiovascular risk or the severity of atherosclerotic vascular damage (Imanishi et al., 2004; Yamashina et al., 2003).

Moreover, it has been shown that baPWV is also correlated with abdominal aortic calcification and long-term cardiovascular risk (Hung et al., 2009; Nakamura et al., 2003). baPWV $>14.0 \mathrm{~m} / \mathrm{sec}$ has been suggested as a cutoff value for screening high-risk individuals for cardiovascular disease (Yamashina et al., 2003).

\subsection{Complement 1 inhibitor has a strong positive correlation with brachial-ankle pulse wave velocity}

Initially, C1 inhibitor was shown to be associated with angioedema, and its deficiency was identified as the cause of hereditary angioedema (Donaldson \& Rosen, 1964; Johnson et al., 1971). However, C1 inhibitor belongs to a group of positive acute phase proteins whose production and release increase during inflammation (Gabay \& Kushner, 1999; Kalter et al., 1985; Woo et al., 1985). C1 inhibitor has a tissue protection effect, and markedly inhibits activation and recruitment of macrophages (Storini et al., 2005). C1 inhibitor also limits neointimal plaque formation by blocking complement activation, inhibiting leukocyte recruitment, and reducing triglyceride levels (Shagdarsuren et al., 2008). Recently, it has been suggested that all of the risk factors for atherosclerosis contribute to its development by aggravating the underlying inflammatory process (Bisoendial et al., 2007; Buono et al., 2002; Kostner et al., 2006; Mallika et al., 2007; Natali et al., 2003; Nicoletti et al., 2000; Ridker \& Silvertown, 2008; van Popele et al., 2001). The inflammatory cytokine interferon- $\gamma$ (IFN- $\gamma$ ) has been demonstrated to be highly expressed in atherosclerotic lesions (McLaren \& Ramji, 2008). IFN- $\gamma$ enhances the expression of $C 1$ inhibitor mRNA, primarily due to an increased transcription rate (Zahedi et al., 1994). Other cytokines, such as tumor necrosis factor- $\alpha$, IFNa, monocyte colony stimulating factor, and interleukin- 6 have also been shown to stimulate the synthesis of C1 inhibitor (Caliezi et al., 2000; Gabay \& Kushner, 1999). Clinically, C1 inhibitor is an independent predictor of cardiovascular disease (Kostner et al., 2006). In the author's study, the serum level of $\mathrm{C} 1$ inhibitor showed a positive correlation with baPWV (Fig. 3, Table 1, 3) (Chae \& Park, 2009).

\begin{tabular}{llcc}
\hline Variables & Regression Coefficient & $P$ & $R^{2}$ \\
\hline Constant & 657.06 & $<0.001$ & \\
Age & 7.365 & $<0.001$ & \\
Gender & -137.521 & $<0.001$ & 0.695 \\
Hypertension & -143.066 & $<0.001$ & \\
Body mass index & 14.605 & 0.006 & \\
C1 inhibitor & 6.367 & 0.025 & \\
\hline
\end{tabular}

Multiple regression analysis (stepwise method); gender ( male $=1$, female $=2$ ); hypertension (yes $=1$, no $=2) ; \mathrm{P}<0.05$ was considered significant.

Table 3. Predictors for brachial-ankle pulse wave velocity in multiple regression analysis 


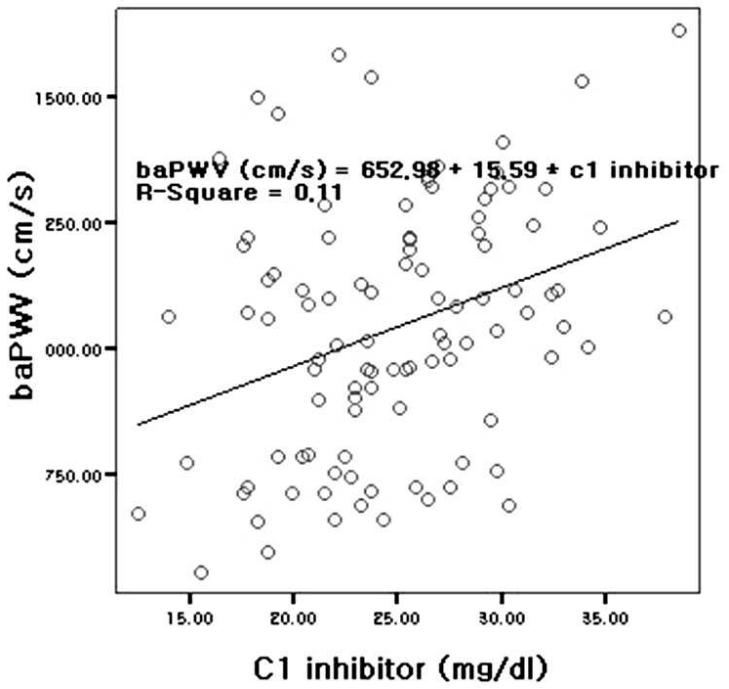

Fig. 3. Linear regression between baPWV and $\mathrm{C} 1$ inhibitor. baPWV showed a trend of positive relationship with the serum level of $\mathrm{C} 1$ inhibitor.

The results of the author's study suggest that the serum level of $\mathrm{C} 1$ inhibitor reflects the degree of arterial stiffness, thus having the potential to predict the severity of atherosclerosis.

\section{Conclusion}

Atherosclerosis is a chronic inflammatory disease of the artery, and activation of the complement system is an important underlying mechanism in atherosclerosis. Increased production of the acute phase protein $\mathrm{C} 1$ inhibitor is a systemic response to local inflammation of the atherosclerotic lesion in the artery. The serum level of $\mathrm{C} 1$ inhibitor has a positive correlation with baPWV, a measure of arterial stiffness. Based on this finding, it is suggested that $\mathrm{C} 1$ inhibitor is associated with atherosclerosis through its association with increased inflammation, and that the acute phase protein $\mathrm{C} 1$ inhibitor is a useful indicator of arterial stiffness. Future research should be directed toward the preventive or therapeutic use of $\mathrm{C} 1$ inhibitor, which will lead to progress in the treatment of atherosclerotic disease.

\section{References}

Abbas, A.K., Lichtman, A.H., \& Pillai, S. (2010) Cellular and Molecular Immunology (international edition), Saunders, ISBN: 0808923587, Philadelphia, PA

Ajjan, R., Grant, P.J., Futers, T.S., Brown, J.M., Cymbalista, C.M., Boothby, M., \& Carter, A.M. (2005) Complement C3 and C-reactive protein levels in patients with stable coronary artery disease. Journal of Thrombosis and Haemostasis, Vol. 94, Issue 5, pp. 1048-1053

Anderson, D.R., Tsutsui, J.M., Xie, F., Radio, S.J., \& Porter, T.R. (2007) The role of complement in the adherence of microbubbles to dysfunctional arterial 
endothelium and atherosclerotic plaque. Cardiovascular Research, Vol. 73, Issue 3, pp. 597-606

Bhatia, V.K., Yun, S., Leung, V., Grimsditch, D.C., Benson, G.M., Botto, M.B., Boyle, J.J., \& Haskard, D.O. (2007) Complement C1q reduces early atherosclerosis in low-density lipoprotein receptor-deficient mice. American Journal of Pathology, Vol. 170, Issue 1, pp. $416-426$

Biro, A., Thielens, N.M., Cervenak, L., Prohaszka, Z., Fust, G., \& Arlaud, G.J. (2007) Modified low density lipoproteins differentially bind and activate the $\mathrm{C} 1$ complex of complement. Molecular Immunology, Vol. 44, Issue 6, pp. 1169-1177

Bisoendial, R.J., Kastelein, J.J., \& Stroes, E.S. (2007) C-reactive protein and atherogenesis: from fatty streak to clinical event. Atherosclerosis, Vol. 195, Issue 2 pp: e10-e18.

Buono, C., Come, C.E., Witztum, J.L., Maguire, G.F., Connelly, P.W., Carroll, M., \& Lichtman, A.H. (2002) Influence of C3 deficiency on atherosclerosis. Circulation, Vol. 105, Issue 25, pp. 3025-3031

Caliezi, C., Wuillemin, W.A., Zeerleder, S., Redondo, M., Eisele, B., \& Hack, C.E. (2000) C1Esterase inhibitor: an anti-inflammatory agent and its potential use in the treatment of diseases other than hereditary angioedema. Pharmacological Reviews, Vol. 52, Issue 1, pp. 91-112

Cao, W., Bobryshev, Y.V., Lord, R.S., Oakley, R.E., Lee, S.H., \& Lu, J. (2003) Dendritic cells in the arterial wall express C1q: potential significance in atherogenesis. Cardiovascular Research, Vol. 60, Issue 1, pp. 175-186

Capuano, V., D'Arminio, T., La Sala, G., \& Mazzotta, G. (2006) The third component of the complement (C3) is a marker of the risk of atherogenesis. European Journal of Cardiovascular Prevention and Rehabilitation, Vol. 13, Issue 4, pp. 658-660

Carter, P.E., Dunbar, B., \& Fothergill, J.E. (1988) Genomic and cDNA cloning of the human C1 inhibitor. Intron-exon junctions and comparison with other serpins. European Journal of Biochemistry, Vol. 173, Issue 1, pp. 163-169

Chae, Y.M. \& Park, J.K. (2009) The relationship between brachial ankle pulse wave velocity and complement 1 inhibitor. Journal of Korean Medical Science, Vol. 24, Issue 5, pp. 831-836

Donaldson, V.H. \& Rosen, F.S. (1964) Action of complement in hereditary angioneurotic edema: the role of C'1-esterase. Journal of Clinical Investigation, Vol. 43, pp. 2204-2213

Einstein, L.P., Hansen, P.J., Ballow, M., Davis, A.E. 3rd, Davis, J.S. 4th, Alper, C.A., Rosen, F.S., \& Colten, H.R. (1977) Biosynthesis of the third component of complement (C3) in vitro by monocytes from both normal and homozygous C3-deficient humans. Journal of Clinical Investigation, Vol. 60, Issue 5, pp. 963-969

Farrar, D.J., Green, H.D., Bond, M.G., Wagner, W.D., \& Gobbee, R.A. (1978) Aortic pulse wave velocity, elasticity, and composition in a nonhuman primate model of atherosclerosis. Circulation Research, Vol. 43, Issue 1, pp. 52-62

Fosbrink, M., Niculescu, F., Rus, V., Shin, M.L., \& Rus, H. (2006) C5b-9-induced endothelial cell proliferation and migration are dependent on Akt inactivation of forkhead transcription factor FOXO1. The Journal of Biological Chemistry, Vol. 281, Issue 28, pp. 19009-19018

Gabay, C. \& Kushner, I. (1999) Acute-phase proteins and other systemic responses to inflammation. New England Journal of Medicine, Vol. 340, Issue 6, pp. 448-454 
Hung CS, Lin JW, Hsu CN, Chen, H.M., Tsai, R.Y., Chien, Y.F., \& Hwang, J.J. (2009) Using brachial-ankle pulse wave velocity to associate arterial stiffness with cardiovascular risks. Nutrition, Metabolism \& Cardiovascular Diseases, Vol. 19, Issue 4, 241-246

Imanishi, R., Seto, S., Toda, G., Yoshida, M., Ohtsuru, A., Koide, Y., Baba, T., \& Yano, K. (2004) High brachial-ankle pulse wave velocity is an independent predictor of the presence of coronary artery disease in men. Hypertension Research, Vol. 27, Issue 2, pp. $71-78$

Jani, B. \& Rajkumar, C. (2006) Ageing and vascular ageing. Postgraduate Medical Journal, Vol. 82, Issue 968, pp. 357-362

Johnson, A.M., Alper, C.A., Rosen, F.S., \& Craig, J.M. (1971) C1 inhibitor: evidence for decreased hepatic synthesis in hereditary angioneurotic edema. Science, Vol. 173, Issue 996, pp. 553-554

Kalter, E.S., Daha, M.R., ten Cate, J.W., Verhoef, J., \& Bouma, B.N. (1985) Activation and inhibition of Hageman factor-dependent pathways and the complement system in uncomplicated bacteremia or bacterial shock. Journal of Infectious Diseases, Vol. 151, Issue 6, pp. 1019-1027

Kim, D.H., Kim, J., Kim, J.M., \& Lee, A.Y. (2008) Increased brachial-ankle pulse wave velocity is independently associated with risk of cerebral ischemic small vessel disease in elderly hypertensive patients. Clinical Neurology and Neurosurgery, Vol. 110, Issue 6, pp. 599-604

Kostner, K.M., Fahti, R.B., Case, C., Hobson, P., Tate, J., \& Marwick, T.H. (2006) Inflammation, complement activation and endothelial function in stable and unstable coronary artery disease. Clinica Chimica Acta, Vol. 365, Issue 1-2, pp. 129-134

Langlois, P.F. \& Gawryl, M.S. (1988) Detection of the terminal complement complex in patient plasma following acute myocardial infarction. Atherosclerosis, Vol. 70, Issue 1-2, pp. 95-105

Lappin, D. \& Whaley, K. (1989) Regulation of C1-inhibitor synthesis by interferons and other agents. Behring Institute Mitteilungen, Vol. 84, pp. 180-192

Leung, V.W., Yun, S., Botto, M., Boyle, J.J.; \& Haskard, D.O. (2009) Decay-accelerating factor suppresses complement $\mathrm{C} 3$ activation and retards atherosclerosis in low-density lipoprotein receptor-deficient mice. American Journal of Pathology, Vol. 175, Issue 4, pp. $1757-1767$

Mallika, V., Goswami, B., \& Rajappa, M. (2007) Atherosclerosis pathophysiology and the role of novel risk factors: a clinicobiochemical perspective. Angiology, Vol. 58, Issue 5, pp. 513-522

McLaren, J.E. \& Ramji, D.P. (2008) Interferon gamma: a master regulator of atherosclerosis. Cytokine \& Growth Factor Reviews, Vol. 20, pp. 125-135

Morgan, B.P. \& Gasque, P. (1997) Extrahepatic complement biosynthesis: where, when and why? Clinical \& Experimental Immunology, Vol. 107, Issue 1, pp. 1-7

Moshage, H. (1997) Cytokines and the hepatic acute phase response. The Journal of Pathology, Vol. 181, Issue 3, pp. 257-266.

Nakamura, U., Iwase, M., Nohara, S., Kanai, H., Ichikawa, K., \& Iida, M. (2003) Usefulness of brachial-ankle pulse wave velocity measurement: correlation with abdominal aortic calcification. Hypertension Research, Vol. 26, Issue 2, pp. 163-167 
Natali, A., L'Abbate, A., \& Ferrannini, E. (2003) Erythrocyte sedimentation rate, coronary atherosclerosis, and cardiac mortality. European Heart Journal, Vol. 24, Issue 7, pp. 639-648

Nicoletti, A., Caligiuri, G., \& Hansson, G.K. (2000) Immunomodulation of atherosclerosis: myth and reality. Journal of Internal Medicine, Vol. 247, Issue 3, pp. 397-405

Niculescu, F., Niculescu, T., \& Rus, H. (2004) C5b-9 terminal complement complex assembly on apoptotic cells in human arterial wall with atherosclerosis. Experimental and Molecular Pathology, Vol. 76, Issue 1, pp. 17-23

Niculescu, F. \& Rus, H. (2004) The role of complement activation in atherosclerosis. Immunologic Research, Vol. 30, Issue 1, pp. 73-80

Oksjoki, R., Kovanen, P.T., \& Pentikainen, M.O. (2003) Role of complement activation in atherosclerosis. Current Opinion in Lipidology, Vol. 14, Issue 5, pp. 477-482

Oksjoki, R., Kovanen, P.T., Mayranpaa, M.I., Laine, P., Blom, A.M., Meri, S., \& Pentikainen, M.O. (2007) Complement regulation in human atherosclerotic coronary lesions. Immunohistochemical evidence that $\mathrm{C} 4 \mathrm{~b}$-binding protein negatively regulates the classical complement pathway, and that C5b-9 is formed via the alternative complement pathway. Atherosclerosis, Vol. 192, Issue 1, pp. 40-48

Prada, A.E., Zahedi, K., \& Davis, A.E. 3rd. (1998) Regulation of C1 inhibitor synthesis. Immunobiology, Vol. 199, Issue 2, pp. 377-388

Ridker, P.M. \& Silvertown, J.D. (2008) Inflammation, C-reactive protein, and atherothrombosis. Journal of Periodontology, Vol. 79, Issue 8 Suppl, pp. 1544-1551

Schepers, A., de Vries, M.R., van Leuven, C.J., Grimbergen, J.M., Holers, V.M., Daha, M.R., van Bockel, J.H., \& Quax, P.H.A. (2006) Inhibition of complement component C3 reduces vein graft atherosclerosis in apolipoprotein E3-Leiden transgenic mice. Circulation, Vol. 114, Issue 25, pp. 2831-2838

Schrijvers, D.M., De Meyer, G.R., Herman, A.G., \& Martinet, W. (2007) Phagocytosis in atherosclerosis: molecular mechanisms and implications for plaque progression and stability. Cardiovascular Research, Vol. 73, Issue 3, pp. 470-480

Seimon, T. \& Tabas, I. (2009) Mechanisms and consequences of macrophage apoptosis in atherosclerosis. The Journal of Lipid Research, Vol. 50 (Suppl), pp. S382-S387

Shagdarsuren, E., Bidzhekov, K., Djalali-Talab, Y., Liehn, E.A., Hristov, M., Matthijsen, R.A., Buurman, W.A., Zernecke, A., \& Weber, C. (2008) C1-esterase inhibitor protects against neointima formation after arterial injury in atherosclerosis-prone mice. Circulation, Vol. 117, Issue 1, pp. 70-78

Storini, C., Rossi, E., Marrella, V., Distaso, M., Veerhuis, R., Vergani, C., Bergamaschini, L., \& De Simoni, M.G. (2005) C1-inhibitor protects against brain ischemia-reperfusion injury via inhibition of cell recruitment and inflammation. Neurobiology of Disease, Vol. 19, Issue 1-2, pp. 10-17

Szeplaki, G., Prohaszka, Z., Duba, J., Rugonfalvi-Kiss, S., Karadi, I., Kokai, M., Kramer, J., Fust, G., Kleiber, M., Romics, L., \& Varga, L. (2004) Association of high serum concentration of the third component of complement (C3) with pre-existing severe coronary artery disease and new vascular events in women. Atherosclerosis, Vol. 177, Issue 2, pp. 383-389

Tanaka, H., Munakata, M., Kawano, Y., Ohishi, M., Shoji, T., Sugawara, J., Tomiyama, H., Yamashina, A., Yasuda, H., Sawayama, T., \& Ozawa, T. (2009) Comparison 
between carotid-femoral and brachial-ankle pulse wave velocity as measures of arterial stiffness. Journal of Hypertension, Vol. 27, Issue 10, pp. 2022-2027

Thorbjornsdottir, P., Kolka, R., Gunnarsson, E., Bambir, S.H., Thorgeirsson, G., Kotwal, G.J., \& Arason, G. (2005) Vaccinia virus complement control protein diminishes formation of atherosclerotic lesions: complement is centrally involved in atherosclerotic disease. Annals of the New York Academy of Sciences, Vol. 1056, pp. 1-15

Tomiyama, H., Yamashina, A., Arai, T., Hirose, K., Koji, Y., Chikamori, T., Hori, S., Yamamoto, Y., Doba, N., \& Hinohara, S. (2003) Influences of age and gender on results of noninvasive brachial-ankle pulse wave velocity measurement--a survey of 12517 subjects. Atherosclerosis, Vol. 166, Issue 2, pp. 303-309

Tomiyama, H., Koji, Y., Yambe, M., Shiina, K., Motobe, M., Yamada, J., Shido, N., Tanaka, N., Chikamori, T., \& Yamashina, A. (2005) Brachial-ankle pulse wave velocity is a simple and independent predictor of prognosis in patients with acute coronary syndrome. Circulation Journal, Vol. 69, Issue 7, pp. 815-822

van Popele, N.M., Grobbee, D.E., Bots, M.L., Asmar, R., Topouchian, J., Reneman, R.S., Hoeks, A.P.G., van der Kuip, D.A.M., Hofman, A., \& Witteman, J.C.M. (2001) Association between arterial stiffness and atherosclerosis: the Rotterdam Study. Stroke, Vol. 32, Issue 2, pp. 454-460

Windfuhr, J.P., Alsenz, J., \& Loos, M. (2005) The critical concentration of C1-esterase inhibitor (C1-INH) in human serum preventing auto-activation of the first component of complement (C1). Molecular Immunology, Vol. 42, Issue 6, pp. 657-663

Woo, P., Lachmann, P.J., Harrison, R.A., Amos, N., Cooper, C., \& Rosen, F.S. (1985) Simultaneous turnover of normal and dysfunctional C1 inhibitor as a probe of in vivo activation of $\mathrm{C} 1$ and contact activatable proteases. Clinical $\mathcal{E}$ Experimental Immunology, Vol. 61, Issue 1, pp. 1-8

Wu, G., Hu, W., Shahsafaei, A., Song, W., Dobarro, M., Sukhova, G.K., Bronson, R.R., Shi, G., Rother, R.P., Halperin, J.A., \& Qin, X. (2009) Complement regulator CD59 protects against atherosclerosis by restricting the formation of complement membrane attack complex. Circulation Research, Vol. 104, Issue 4, pp. 550-558

Wykretowicz, A., Gerstenberger, P., Guzik, P., Milewska, A., Krauze, T., Adamska, K., Rutkowska, A., \& Wysocki, H. (2009) Arterial stiffness in relation to subclinical atherosclerosis. European Journal of Clinical Investigation, Vol. 39, Issue 1, pp. 11-16

Xu, Y., Wu, Y., Li, J., Ma, W., Guo, X., Luo, Y., \& Hu, D. (2008) The predictive value of brachial-ankle pulse wave velocity in coronary atherosclerosis and peripheral artery diseases in urban Chinese patients. Hypertension Research, Vol. 31, Issue 6, pp. 1079-1085

Yamashina, A., Tomiyama, H., Takeda, K., Tsuda, H., Arai, T., Hirose, K., Koji, Y., Hori, S., \& Yamamoto, Y. (2002) Validity, reproducibility, and clinical significance of noninvasive brachial-ankle pulse wave velocity measurement. Hypertension Research, Vol. 25, Issue 3, pp. 359-364

Yamashina, A., Tomiyama, H., Arai, T., Hirose, K., Koji, Y., Hirayama, Y., Yamamoto, Y., \& Hori, S. (2003) Brachial-ankle pulse wave velocity as a marker of atherosclerotic vascular damage and cardiovascular risk. Hypertension Research, Vol. 26, Issue 8, pp. $615-622$ 
Yasojima, K., Schwab, C., McGeer, E.G., \& McGeer, P.L. (2001) Complement components, but not complement inhibitors, are upregulated in atherosclerotic plaques. Arteriosclerosis, Thrombosis, and Vascular Biology, Vol. 21, Issue 7, pp. 1214-1219

Yun, S., Leung, V.W., Botto, M., Boyle, J.J., \& Haskard, D.O. (2008) Brief report: accelerated atherosclerosis in low-density lipoprotein receptor-deficient mice lacking the membrane-bound complement regulator CD59. Arteriosclerosis, Thrombosis, and Vascular Biology, Vol. 28, Issue 10, pp. 1714-1716

Zahedi, K., Prada, A.E., \& Davis, A.E. 3rd. (1994) Transcriptional regulation of the C1 inhibitor gene by gamma-interferon. The Journal of Biological Chemistry, Vol. 269, Issue 13, pp. 9669-9674

Zanker, K.S. (2008) General introduction to innate immunity: Dr. Jekyl/Mr. Hyde quality of the innate immune system. Contributions to Microbiology, Vol. 15, pp. 12-20

Zuraw, B.L. \& Lotz, M. (1990) Regulation of the hepatic synthesis of C1 inhibitor by the hepatocyte stimulating factors interleukin 6 and interferon gamma. The Journal of Biological Chemistry, Vol. 265, Issue 21, pp. 12664-12670 
ACUTE PHASE PROTEINS AS EARIY NON-SPECIFIC BIOMARKERS OF HUMAN ANO VETERINARY DISEASES

Edited by Francheo Vees

\section{Acute Phase Proteins as Early Non-Specific Biomarkers of Human and Veterinary Diseases}

Edited by Prof. Francisco Veas

ISBN 978-953-307-873-1

Hard cover, 408 pages

Publisher InTech

Published online 10, October, 2011

Published in print edition October, 2011

The two volumes of Acute Phase Proteins book consist of chapters that give a large panel of fundamental and applied knowledge on one of the major elements of the inflammatory process during the acute phase response, i.e., the acute phase proteins expression and functions that regulate homeostasis. We have organized this book in two volumes - the first volume, mainly containing chapters on structure, biology and functions of APP, the second volume discussing different uses of APP as diagnostic tools in human and veterinary medicine.

\section{How to reference}

In order to correctly reference this scholarly work, feel free to copy and paste the following:

Jong Kwon Park (2011). The Acute Phase Protein Complement 1 Inhibitor is an Indicator of Arterial Stiffness, Acute Phase Proteins as Early Non-Specific Biomarkers of Human and Veterinary Diseases, Prof. Francisco Veas (Ed.), ISBN: 978-953-307-873-1, InTech, Available from: http://www.intechopen.com/books/acute-phaseproteins-as-early-non-specific-biomarkers-of-human-and-veterinary-diseases/the-acute-phase-proteincomplement-1-inhibitor-is-an-indicator-of-arterial-stiffness

\section{INTECH}

open science | open minds

\section{InTech Europe}

University Campus STeP Ri Slavka Krautzeka 83/A 51000 Rijeka, Croatia Phone: +385 (51) 770447

Fax: +385 (51) 686166 www.intechopen.com

\section{InTech China}

Unit 405, Office Block, Hotel Equatorial Shanghai No.65, Yan An Road (West), Shanghai, 200040, China 中国上海市延安西路65号上海国际贵都大饭店办公楼405单元 Phone: +86-21-62489820

Fax: $+86-21-62489821$ 
(C) 2011 The Author(s). Licensee IntechOpen. This is an open access article distributed under the terms of the Creative Commons Attribution 3.0 License, which permits unrestricted use, distribution, and reproduction in any medium, provided the original work is properly cited. 